\title{
ANALISIS STATUS ASAM ASCORBAT, NILAI LIMFOSIT DAN LAMA PENGOBATAN PASIEN TB MDR DI RSUD SOEWONDO PATI
}

\author{
Sifa Altika ${ }^{1}$, Irfana Tri Wijayanti ${ }^{2}$ \\ ${ }^{1}$ Dosen Program Studi Diploma Tiga Kebidanan STIKes Bakti Utama Pati \\ ${ }^{2}$ Dosen Program Studi Sarjana Kebidanan STIKes Bakti Utama Pati \\ Alamat Korespondensi: $\underline{\text { sifa.altika@gmail.com }}$
}

\begin{abstract}
Abstrak
TB MDR merupakan infeksi yang disebabkan oleh micobakterium tuberculosis yang resisten terhadap 2 atau lebih OAT. Resistensi OAT menyebabkan peningkatan radikal bebas dan penurunan antioksidan, salah satu jenis antioksidan dalam tubuh adalah asam ascobat. Tujuan dalam penelitian ini adalah menganalisis status asam ascorbat, nilai limfosit dan lama pengobatan pasien TB-MDR dengan dilakukan pemeriksaan untuk mendeteksi, mengukur dan menganalisis status asam ascorbat, nilai limfosit, serta lama pengobatan pasien TB MDR. Penelitian menggunakan case control (kasus kontrol). Jumlah sampel yang digunakan adalah total sampling dengan perbandingan 1:1 antara kelompok kasus dan kelompok kontrol, Sampel diperoleh berdasarkan urutan kedatangan pasien berobat ke RSUD Soewondo Pati selama periode penelitian (consecutive sampling). Sampel penelitian ini adalah 20 kelompok kasus dan 20 kelompok control. Berdasarkan uji Mann Whitney menunjukkan bahwa terdapat perbedaan antara total asam ascorbat pada kelompok kasus dan kelompok control dengan nilai $\mathrm{p}=0,027<0,05$. Serta terdapat perbedaan nilai limfosit pada kelompok kasus dan kelompok control $p=0,000<0,05$. Berdasrkan hasil tersebut rerata nilai limfosit dan asam ascorbat kelompok control lebih tinggi di bandingkan dengan kelompok kasus (pasien TB MDR), Meskipun menunjukkan adanya perbedaan nilai limfosit pada kelompok kasus dan control menunjukkan bahwa rerata masing-masing kelompok menunjukkan defisiensi Vit C. Berdasarkan hasil penelitian disarankan untuk pengembangkan intervensi pemberian Vit. $\mathrm{C}$ terhadap perceatan penyembuhan pasien TB MDR.
\end{abstract}

Kata Kunci: asam ascorbat, limfosit, lama pengobatan, TB-MDR.

\begin{abstract}
TB MDR is an infection caused by mycobacterium tuberculosis that is resistant OATs. OAT resistance causes an increase in free radicals and a decrease in antioxidants, one type of antioxidant in the body is ascobat acid. The purpose of this study was to analyze the ascorbic acid status, lymphocyte value and duration of treatment for TB MDR patients by conducting tests to detect, measure and analyze ascorbic acid status, lymphocyte values, and length of treatment for TB MDR patients. This study uses a case control. The sample used total sampling with a ratio of 1: 1 between the case group and the control group. Samples were obtained based on the order in which the patients visited RSUD Soewondo Pati during the study period (consecutive sampling). The sample of this study was 20 case groups and 20 control groups. The results of this study based on the Mann Whitney test, it shows that there is a difference between the total ascorbic acid in the case group and the control group with a value of $p=0.027<0.05$. And there is a difference in lymphocyte values in the case group and the control group $\mathrm{p}=0.000<0.05$. Based on these results the mean lymphocyte and ascorbic acid values of the control group were higher than the case group, although showing differences in lymphocyte values in the case and control groups showed that the mean of each group showed Vitamin $\mathrm{C}$ deficiency. Based on the results of the study, it is suggested to develop interventions giving Vitamin $\mathrm{C}$ to the perceived healing of TB MDR patients.
\end{abstract}

Keywords: ascorbic acid, lymphocytes, length of treatment, TB MDR 


\section{PENDAHULUAN}

World health organization (WHO) tahun 2014 diperkirakan 9 juta penduduk dunia telah terinfeksi kuman TB (WHO, 2015), tahun 2014 diperkirakan 9,6 juta orang telah jatuh sakit dengan TB (WHO, 2016). Angka kasus TB selalu mengalami peniningkatan dari tahun 2015- 2016. Penatalaksanaan kasus TB yang kurang baik dapat mengakibatkan terjadinya resistensi OAT. Resistensi OAT sebagian besar disebabkan karena ketidak teraturan dalam pengobatan, bertempat tinggal didaerah endemik TB MDR, kontak erat dengan penderita TB MDR dan merakok (Ruddy et al 2005). Indonesia berada di tingkat 8 dari 27 negara dengan beban TB MDR terbanyak di dunia dengan perkirakan pasien TB MDR di Indonesia sebesar 6900 yaitu $1,9 \%$ dari kasus baru dan $12 \%$ dari kasus pengobatan ulang. (Pusat Data dan Informasi Kemenkes RI, 2017).

TB MDR disebabkan oleh infeksi kuman $\mathrm{M}$ tuberculosis yang resisten terhadap dua atau lebih OAT. Tuberculosis yang resistens akan menyebabkan penurunan antioksidan dan peningkatan Kata kunci maksimal 5 kata Latar belakang penelitian tidak lebih dari 500 kata yang berisi latar belakang dan permasalahan yang akan diteliti, tujuan khusus, dan urgensi penelitian. Pada bagian ini perlu dijelaskan uraian tentang spesifikasi khusus terkait dengan skema. Reaktive Oxygen Species (ROS) oleh leukosit polimorfonuklear sebagai respon terhadap endotoksin (Yuniastuti, 2013). Resistensi OAT menyebabkan peningkatan radikal bebas dan penurunan antioksidan, salah satu jenis antioksidan dalam tubuh adalah asam ascobat, Berdasarkan penelitian terdahulu menunjukkan bahwa pada pasien TB paru terjadi penurunan vitamin C (Mohod et al 2011). Semakin besar jumlah vitamin $\mathrm{C}$ dalam tubuh semakin besar leukosit untuk melawan penyakit. Diantara beberapa jenis leukosit, Limfosit merupakan sel yang sangat berperan dalam mempertahankan daya tahan tubuh. Vitamin $\mathrm{C}$ yang berfungsi mempertahankan banyak kofaktor logam dalam keadaan tereduksi serta melindungi biomembran terhadap kerusakan oksidatif (Bander, 2009). Penderita resistensi OAT yang kurang gizi akan mengakibatkan produksi antibody dan limfosit terhambat sehingga proses penyembuhan akan terhambat pula (Thaha, 2010).

Dugaan muncul terjadinya stress oksidatif akibat penurunan asam askorbat sehingga akan mempengaruhi nilai limfosit yang disebabkan oleh infeksi $M$ tuberculosis dan obat anti tuberculosis. Pemeriksaan asam askorbat dan limfosit pada pasien TB MDR juga belum pernah dilakukan, sehingga perlu dilakukan penelitian untuk mengukur dan menganalisis status asam askorbat dan nilai limfosit pada pasien TB MDR di RSUD Soewondo Pati. Berdasarkan hasil laporan Dinkes Kota Pati RSUD Soewondo Pati merupakan rumah sakit dengan penemuan kasus terbanyak di antara pelayanan kesehatan di kota Pati, yaitu didapatkan bahwa jumlah pasien yang didiagnosis dengan TB paru tahun 2019 sebanyak 864 kasus dan dengan status TB MDR sebanyak 20 kasus. Tujuan penelitian ini adalah Menganalisis status asam askorbat, nilai limfosit dan lama pengobatan pasien TB MDR di RSUD Soewondo Pati.

\section{METODE PENELITIAN}

Jenis penelitian yang di gunakan adalah case control (kasus kontrol). 
Sample yang digunakan dalam penelitian ini adalah total sampling dengan teknik pengambilan sampel selama periode penelitian (consecutive sampling). Dengan perbandingan 20 kasus dan 20 kontrol.

Cara pengumpulan data penelitian ini adalah menggunakan data primer dan sekunder. Data primer yang dilakukan dengan pengambilan sampel darah pada pasien TB MDR dan non TB MDR. Sedangkan data sekunder yaitu data untuk menunjang yang dilihat berdasarkan catatan rekam medik pasien

yang di antaranya tahapan fase pengobatan, dan waktu mulai pengobatan.

Analisis dilakukan dengan pengujian statistik dengan menggunakan uji mann withny untuk melihat perbedaan status asama ascorbat dan limfosit pada kelompok kasus dan control. Penelitian ini biayai oleh DRPM, berdsarkan Kontrak Penelitian Tahun Anggaran 2020, Nomer: 075/LL6/PG/SP2H/PL.II/2020.

\section{HASIL PENELITIAN}

Tabel 1 .

Distribusi Frekuensi Karakteristik Jenis Kelamin Kelompok Kasus dan Kontrol

\begin{tabular}{|l|l|l|r|r|r|}
\hline & & & \multicolumn{2}{|c|}{ JenisKelamin } & \multirow{2}{*}{ Total } \\
\cline { 3 - 6 } & & & $\mathrm{L}$ & \multicolumn{1}{c|}{$\mathrm{P}$} & 20 \\
\hline \multirow{2}{*}{ Kelompok } & kasus & $\mathrm{n}$ & 12 & 8 & $20.0 \%$ \\
& & $\%$ & $30.0 \%$ & $20.0 \%$ & $50.0 \%$ \\
\cline { 2 - 6 } & \multirow{2}{*}{ Kontrol } & $\mathrm{n}$ & 10 & 10 & 20 \\
& & $\%$ & $25.0 \%$ & $25.0 \%$ & $50.0 \%$ \\
\hline Total & $\mathrm{n}$ & 22 & 18 & 40 \\
& & $\%$ & $55.0 \%$ & $45.0 \%$ & $100.0 \%$ \\
\hline
\end{tabular}

Tabel 1 menyajikan distribusi yaitu sebanyak 22 orang $(55.0 \%)$ dan sampel penelitian berdasarkan jenis kelamin. Subyek laki-laki lebih tinggi

prempuan 18 orang $(45.0 \%)$

Tabel 2.

Rerata usia responden

\begin{tabular}{|c|c|c|c|c|}
\hline & Kelompok & Rerata \pm s.d & $\mathbf{n}$ & $\begin{array}{c}\text { Maximum- } \\
\text { minimun }\end{array}$ \\
\hline \multirow[t]{2}{*}{ Usia } & kasus & $43.00 \pm 12.307$ & 20 & $60-19$ \\
\hline & kontrol & $44.50 \pm 10.670$ & 20 & $62-19$ \\
\hline
\end{tabular}

Tabel 2 Rerata usia responden kelompok kasus adalah $43.00 \pm$ 12.307, dan rerata usia responden pada kelompok control adalah $44.50 \pm 10.670$.

Tabel 3. 
Rerata Lama Pengobatan Pasien TB MDR

\begin{tabular}{lccc} 
& Rerata \pm s.d & n & $\begin{array}{c}\text { Maximum- } \\
\text { minimun }\end{array}$ \\
\hline Lama & $7.75 \pm 1.997$ & 20 & $12-5$
\end{tabular}

Tabel 3 Rerata lama pengobatan

dengan pengobatan paling lama pasien TB MDR di RSUD

Soewondo adalah $7.75 \pm 1.997$, responden 12 bulan.

Tabel 4 .

Rerata Nilai Limfosit

\begin{tabular}{|c|c|c|c|c|c|}
\hline & Kelompok & Rerata \pm s.d & $\mathbf{n}$ & $\begin{array}{l}\text { Maximum- } \\
\text { minimun }\end{array}$ & $\mathbf{p}$ \\
\hline Nilai & kasus & $15.75 \pm 1.796$ & 20 & $19.21-13.97$ & \multirow[b]{2}{*}{0.000} \\
\hline$\underset{t}{\operatorname{Limfosi}}$ & i kontrol & $32.89 \pm 5.728$ & 20 & $40.64-25.00$ & \\
\hline
\end{tabular}

Tabel 4 Berdasarkan uji normalitas Kolmogorov-Smirnov data total status antioksidan berdistribusi tidak normal, sehingga dilakukan uji beda antar variabel menggunakan uji Mann Whitney dengan tingkat kemaknaan $\mathrm{p}<0,05$, hasil uji statistic menunjukkan Nilai Limfosit responden berdasarkan pemeriksaan Limfosit didapatkan rerata $15.75 \pm 1.796$ pada kelompok kasus (pasien TB MDR) lebih rendah dibandingkan dengan rerata pada kelompok control $32.89 \pm 5.728$. Hal ini menunjukkan bahwa rata-rata nilai limfosit pasien TB MDR di bawah batas normal limfosit yaitu (25.0-40.0\%). Hasil statistik berdasarkan uji mann whitney didapatkan $\mathrm{p}=0,000<0,05$, maka dapat disimpulkan terdapat perbedaan antara Nilai Limfosit pada kelompok kasus dan kelompok control.

Tabel 5.

Rerata Asam Ascorbat

\begin{tabular}{llllll}
\hline & Kelompok & Rerata \pm s.d & n & $\begin{array}{c}\text { Maximum- } \\
\text { minimun }\end{array}$ & p \\
\cline { 1 - 4 } $\begin{array}{l}\text { Nilai } \\
\text { Limfosit }\end{array}$ & kasus & $0.58 \pm \mathbf{0 . 7 0 2}$ & 20 & $2.18-0.60$ & 0,027 \\
\cline { 2 - 5 } & kontrol & $0.99 \pm \mathbf{0 . 8 1 1}$ & 20 & $2.34-0.11$ & \\
\hline
\end{tabular}

Tabel 5 Berdasarkan uji normalitas Kolmogorov-Smirnov data asam askorbat berdistribusi tidak normal, sehingga dilakukan uji beda antar variabel menggunakan uji Mann Whitney dengan tingkat kemaknaan $\mathrm{p}<0,05$. Hasil uji statistik menunjukkan bahwa terdapat perbedaan antara total asam ascorbat pada kelompok kasus dan kelompok control dengan nilai $\mathrm{p}=0,027<0,05$. Berdasrkan hasil tersebut rerata nilai asam askorbat kelompok control lebih tinggi di bandingkan dengan kelompok kasus (pasien TB MDR), Meskipun menunjukkan adanya perbedaan nilai asam ascorbat pada kelompok kasus dan control menunjukkan bahwa rerata masingmasing kelompok menunjukkan defisiensi Vit C 


\section{PEMBAHASAN}

Pengembangan pengobatan TB paru yang efektif merupakan hal yang penting untuk menyembuhkan pasien dan menghindari MDR TB (multidrug resistant tuberculosis). Pengembangan strategi DOTS untuk mengontrol epidemi TB paru merupakan prioritas utama WHO. Obat yang digunakan terdiri dari paduan obat utama dan tambahan. Pasien dievaluasi setiap 2 minggu pada 1 bulan pertama pengobatan selanjutnya setiap 1 bulan. Evaluasi dilakukan $0-2-6 / 9$ bulan pengobatan (Perhimpunan Dokter Paru Indonesia, 2006).

Rerata lama pengobatan pasien TB MDR di RSUD Soewondo adalah 7.75 \pm 1.997, dengan pengobatan paling lama responden 12 bulan. Adanya perbedaan pengobatan pada kasus TB paru menurut jenjang fase pengobatan dapat memberikan pengaruh terhadap tubuh melihat efek samping dari pengobatan pada pasien TB paru diantaranya Tidak nafsu makan, mual, sakit perut yang dapat menyebabkan menurunnya status gizi responden selain itu sebagian besar dari OAT dapat menyebabkan ikterik atau hepatitis imbas dari obat. Melihat efek samping dari penggunaan OAT, yang merupakan bahan kimia yang dapat menyebabkan perubahan metaboisme tubuh.

Mekanisme resistensi OAT merupakan analisis secara genetik dan molecular pada $M$ tuberculosis menjelaskan bahwa mekanisme resistensi biasanya didapat oleh basil melalui mutasi terhadap target obat atau oleh titrasi dari obat akibat over produksi dari target. Resistensi hanya bisa tejadi karena mutasi genetik dari $M$ tuberculosis itu sendiri, dan mutasi tersebut terjadi secara alami, tidak ada pengaruh dari OAT. Penyebaran resistensi $M$ tuberculosis terjadi setelah amplifikasi kuman resisten sebagi akibat pemberian obat yang tidak adekuat (Syahrini 2008). Mutasi berupa substitusi asam amino, perubahan kodon menjadi kodon stop sehingga enzim dihasilkan berukuran lebih pendek sehingga hilang aktivitas enzimatiknya atau aktivitas pengikutnya (Retnoningrum dkk 2004).

Lama pengobatan TB-MDR seluruhnya paling sedikit 18 bulan setelah konversi biakan. Lama pengobatan berkisar $19-24$ bulan yang terdiri dari pengobatan tahap awal dan tahap lanjutan. Pengobatan pasien TB MDR menggunakan paduan OAT yang terdiri dari OAT lini pertama dan lini kedua, yang dibagi dalam 5 kelompok berdasar potensi dan efikasinya.

Pada sebuah penelitian dengan menggunakan kelinci percobaan, terbukti bahwa kerja sel darah putih atau leukosit memerlukan kehadiran vitamin C. Menurut Smeltzer \&Bare (2002) sel darah putih merupakan sel dimana didalamnya terdapat komponen sistem imun. Semakin besar jumlah vitamin C dalam tubuh semakin besar leukosit untuk melawan penyakit. Diantara beberapa jenis leukosit, limfosit merupakan sel yang sangat berperan dalam mempertahankan daya tahan tubuh karena berjuang melawan sel - sel kanker.Vitamin $\mathrm{C}$ berperan untuk mengatur pembentukan limfosit dan mengangkut limfosit ketempat terjadinya infeksi (bagian tubuh yang terluka) (Nugroho, 2013).

Leukosit dan turunannya merupakan sel dan struktur dalam tubuh manusia yang didistribusikan keseluruh tubuh dengan fungsi utamanya melindungi organisme terhadap invasi dan pengrusakan oleh mikro organisme dan benda asing lainnya. Sel-sel limfosit ini, mempunyai kemampuan untuk 
membedakan dirinya sendiri (makromolekuler organisme sendiri) dari yang bukan diri sendiri (benda asing) dan mengatur penghancuran dan inaktivasi dari benda asing yang mungkin merupakan molekul yang terisolasi atau bagian dari mikro organisme (Effendi, 2003).

Berdasarkan uji normalitas Kolmogorov-Smirnov data total status antioksidan berdistribusi tidak normal, sehingga dilakukan uji beda antar variabel menggunakan uji Mann Whitney dengan tingkat kemaknaan $\mathrm{p}<0,05$, hasil uji statistic menunjukkan Nilai Limfosit responden berdasarkan pemeriksaan Limfosit didapatkan rerata $15.75 \pm 1.796$ pada kelompok kasus (pasien TB MDR) lebih rendah dibandingkan dengan rerata pada kelompok control $32.89 \pm 5.728$. Hal ini menunjukkan bahwa rata-rata nilai limfosit pasien TB MDR di bawah batas normal limfosit yaitu (25.0-40.0\%). Hasil statistik berdasarkan uji mann whitney didapatkan $\mathrm{p}=0,000<0,05$, maka dapat disimpulkan terdapat perbedaan antara Nilai Limfosit pada kelompok kasus dan kelompok control.

Rata-rata nilai limfosit pada kelompok kasus lebih rendah hal ini dikarenakan Micobakterium tuberkulosis dikenali oleh sistem imunitas tubuh melalui dinding selnya yang mengandung lipopolisakarida (LPS). Lipopolisakrida adalah bagian dari dinding sel bakteri bagian luar terdiri atas komponen lipid dan polisakarida yang merupakan stimulator poten bagi sistem imunitas alamiah. Lipopolisakarida mula-mula diikat oleh protein terlarut darah/cairan ekstraselular yang disebut LPS-binding protein (LBP). Kompleks LPS-LBP akan menfasilitasi peningkatan LPS ke molekul CD14, semua molekul yang terdapat dalam membran plasma sel fogosit atau terlarut dalam plasma. LBP akan melepaskan diri dari LPS setelah LPS terikat pada CD14 dan kompleks LPS-CD14 bergabung dengan Toll-like reseptor 4 (TLR-4) suatu protein yang dapat mengenal molekul mikroba, menstimulasi respon imun (Yuniastuti, 2013).

Infeksi MTB akan merangsang makrofag melepaskan Interlukin-12 baik secara langsung maupun tidak langsung. Interlukin-12 berperan dalam pembentukan sel Th1. Selanjutnya bekerjasama dengan IL-1 dan TNF- $\alpha$ (Sharma et al., 2010) merangsang sel $\mathrm{T}$ dan sel Nk menghasilkan IFN- $\gamma$. Interferon- $\gamma$ tersebut akan mengaktifkan makrofag alveolar untuk memproduksi berbagai maca substansi, diantaranya adalah Reactive Oxygen Species (ROS) dan Reactive Nitrogen Species (RNS), serta Inducible Nitric Oxide Synthetase (iNOS) kedua senyawa ini akan menghambat dan mebunuh kuman (Ehrt and Schnappinger, 2009).

Peningkatan produksi dan pembentukan ROS dapat memicu kejadian stres oksidatif yaitu ketidak seimbangan antara oksidan dan antioksidan. Rendahnya antioksidan berpengaruh terhadap sel tubuh. Fungsi dari antioksidan yaitu melindungi sel dari pengaruh toksik ROS dan RNS, regulasi fungsi sel imun (Winarsi, 2007).

Antioksidan seperti glutation berperan sangat penting dalam melindungi sel, berfungsi dalam pembentukan, pembelahan, proliferasi dan mempertahankan sel limfosit $\mathrm{T}$ yang merupakan mekanisme terdepan pertahanan terhadap infeksi dan sebagai sistem imunitas. Seperti pada umumnya, poliferasi, pertumbuhan dan diferensiasi sel imun sangat tergantung pada glutation (Yuniastuti et al., 2013).

Dalam tubuh asam ascorbat atau di sebut sebagai vitamin $\mathrm{C}$ berfungsi dalam fungsi biochemical tubuh, diantaranya biosintesis amino acid dan 
katekolamin di sistem saraf, membantu absorbsi besi dan menstimulasi aktivitas antibodi dan sel sistem imun sistem imun terbentuk dari sel-sel darah putih, sumsum tulang dan jaringan limfiot, diantara sel darah putih (leukosit) yang terlibat dalam imunitas adalah limfosit B (sel B) dan limfosit T(selT) (Dejaco, 2006) Long (2003) menyatakan bahwa pemberian vitamin $\mathrm{C}$ dapat melindungi sel dari kerusakan radikal bebas dan bermanfaat untuk sel bertahan hidup. Kelebihan radikal bebas akan diredam oleh antioksidan. Ketidakseimbangan antara radikal bebas dan antioksidan akan menimbulkan oxidative stress. Oxidative stress diduga mendasari patofisiologi penyakit kritis, terjadi kegagalan organ Reactive oxygen species (ROS) dan Reactive nitrogenoxygen species (RNOS) sudah jelas memegang peranan dalam modulasi cell signaling, proliferasi, apoptosis dan protesksi sel. Selebihnya ROS atau RNOS dapat memacu pelepasan sitokin dari sel imun, mengaktivasi kaskade inflamasi dan meningkatkan ekspresi adhesi molekul yang diperantarai melalui peningkatan ekspresi nuclear factor kappa $\beta$ sehingga inflamasi dan trauma jaringan berakibat akumulasi granulosit pada organ yang mengakibatkan terjadi peningaktan generasi ROS dan respons inflamasi berlipat ganda serta memperparah kerusakan jaringan.

\section{KESIMPULAN DAN SARAN}

Terdapat perbedaan nilai limfosit dan status asama ascorbat pasien TB MDR, Berdasrkan hasil tersebut rerata nilai limfosit kelompok control lebih tinggi di bandingkan dengan kelompok kasus (pasien TB MDR), rendahnya nilai limfosit kelompok kasusu menunjukaan adanya infeksi dan rendahnya system imunitas pasien TB MDR. Meskipun menunjukkan adanya perbedaan nilai limfosit dan status asam ascorbat pada kelompok kasus dan control menunjukkan bahwa rerata status asam ascorbat masing-masing kelompok menunjukkan defisiensi Vit $\mathrm{C}$

Antioksidan memiliki aktivitas antimikroba langsung yang berbeda dari perannya yaitu sebagai pembawa Nitric oxide (NO). Adanya perbedaan yang sangat penting bahwa peran NO dalam imunitas mikobakteri manusia tidak pasti. Meskipun NO dianggap sebagai molekul efektor utama yang terlibat dalam pengendalian infeksi MTB dan memiliki aktivitas bioligis pendek karena mampu mendetoksifikasi dengan cepat sebagai nitrat dan nitrit. Ketika antioksidan berhubungan langsung dengan sel imun diharapkan dapat mematikan MTB yang artinya pertahan tubuh terhadap mikroba sangat baik. Akan tetapi perlu diketahui NO juga bereaksi dengan antioksidan yang dapat menurunkan status kadar antioksidan itu sendiri.

Penurunan total status antioksidan diduga akibat terjadinya keparahan penyakit akibat MTB yang menyebabkan peningkatan radikal bebas. Akibat peningkatan radikal bebas yang melebihi kapasitas menyebabkan rendahnya status kadar antioksidan (Altika, S \& Rahayu, R 2017)

\section{DAFTAR PUSTAKA}

Altika, S., \& Rahayu, R. S. R. (2017). Analisis Total Status Antioksidan (TSA) Pasien Tuberkulosis (TB) Paru Kelompok Usia 30-60 Tahun di Wilayah Kerja Puskesmas Kecamatan Genuk Kota Semarang. Public Health Perspective Journal, 2(3).

Dejaco, C. (2006) inbalance of regulation Tcell in humman autoimmune disease.Immunologi jurnal.vol 117:289 maret 2006.

Effendi, Z., 2003b. Peranan Leukosit 
Sebagai Anti Inflamasi Alergik Dalam Tubuh. Histologi, pp.1-8.

Ehrt, S. \& Schnappinger, D., 2009. Microreview Mycobacterial survival strategies in the phagosome : defence against host streses. Cellular Microbiology, 11(8), pp.1170-1178.

Long, J.A., and Kramer, M., 2003. Effect of Vitamin $\mathrm{E}$ on Lipid Peroxidation and Fertility After Artificial Insemination with Liquid-Stored Turkey Semen. Journal Poultry Science 82: 18021807

http://ps.fass.org/content/82/11/1 802.full.pdf + html

Nugroho, E. J. (2014). Pengaruh Pemberian Vitamin $C$ Terhadap Nilai Limfosit Pada Pasien Tuberculose Di Wilayah Kerja Puskesmas Kradenan Kabupaten Grobogan (Doctoral dissertation, Universitas Muhammadiyah Surakarta).

Retnoningrum, D.S. \& Kembaren, roga F., 2004. Mekanisme Tingkat Molekul Resistensi terhadap Beberapa Obat pada Mycobacterium Tuberculosis. Acta Pharmaceutica Indonesia, XXIX(3), pp.92-95.

Ruddy, M. et al., 2005. Rates of drug resistance and risk factor analysis in civilian and prison patients with tuberculosis in Samara Region, Russia. Thorax, 60, pp.130-136.
Sharma, S. et al., 2010. Genetic polymorphisms in TNF genes and tuberculosis in North Indians. BMC Infectious Deseases, (10), p.165.

Smelzer, S.C.Bare.B.D.(2002) Brunner dan Suddarth's Texbook of medical surgical nursing.Jakarta : ECG.

Syahrini, H., 2008. "Tuberkulosis Paru Resistensi Ganda". Tesis. Universitas Sumatra Utara.

Thaha, I. \& Wahiduddin, 2010. "Analisi Epidemiologi pada Penderita Resistensi Thaha, I. \& Wahiduddin, 2010. "Analisi Epidemiologi pada Penderita Resistensi.

WHO, 2015. Global Tuberculosis Report 2015, France.

Winarsi, H., 2007. Antiolsidan Alami \& Radikal Bebas 5th ed., Yogyakarta.

World Health Organization, 2016. Global tuberculosis report 2016, Switzerland.

Yuniastuti, A. et al., 2013. Status Antioksidan Glutation pada Pasien Tuberkulosis Paru di Balai Kesehatan Paru (BKPM) Makasar. Journal of Biology \& Biology Education, 5(2). Available at: http://journal.unnes.ac.id/nju/inde x.php/biosaintifika. 